\title{
INDOMETHACIN IN THE TREATMENT OF RHEUMATOID ARTHRITIS
}

\section{A CONTROLLED TRIAL COMPARING INDOMETHACIN, PHENYLBUTAZONE, AND PLACEBO}

\author{
BY \\ V. WRIGHT, 1 W. C. WALKER, ${ }^{2}$ AND R. J. MCGUIRE ${ }^{3}$ \\ From the Rheumatism Research Unit, University Department of Medicine and Psychiatry, \\ General Infirmary at Leeds, and The Royal Bath Hospital, Harrogate
}

The introduction of new therapeutic agents if often followed by a period of initial enthusiasm, succeeded by one of caution, and then after clinical trial and experience, drugs find their rightful place in medical treatment.

Since its introduction in 1962, indomethacin has acquired an established place in the treatment of acute gout (Emmerson, 1967). It also seems to be effective in ankylosing spondylitis (Hart and Boardman, 1965) and a controlled short-term trial showed benefit in osteoarthrosis of the hip (Wanka and Dixon, 1964). In rheumatoid arthritis reports have varied from enthusiastic (Kelly, 1964) to "no advantage over aspirin" (Pinals and Frank, 1967) and "no advantage over placebo" (Co-operating Clinics, 1967). There is other evidence that it is comparable to phenylbutazone (Hart and Boardman, 1965). The toxic effects of the latter preparation are well known and several fatal reactions have been encountered, but although side-effects are quite common with indomethacin, it is in general a safe drug. If, therefore, indomethacin is as effective as phenylbutazone in rheumatic disorders, the safety factor clearly represents an important advantage.

To resolve the conflicting views, a trial to compare the two preparations with each other and with a placebo has been conducted, carefully designed to overcome the difficulties inherent in such an investigation.

\section{Selection of Patients}

A total of 24 patients with definite rheumatoid arthritis (Ropes, Bennett, Cobb, Jacox, and Jessar, 1959) completed the trial. Three others dropped out for reasons discussed later. All patients had had bilateral involvement of the wrist and hands for at least one year

\footnotetext{
'Senior Lecturer, Consultant Physician in Rheumatology.

¿Consultant Physician, Wakefield Hospitals.
}

${ }^{3}$ Senior Lecturer in Clinical Psychology. and a raised erythrocyte sedimentation rate (ESR) at the time of study. No patient over the age of 75 was admitted to the trial. None had received gold, antimalarial drug therapy, corticosteroids, or phenylbutazone for the preceding month. Any patient giving a history of dyspepsia not related to medication during the preceding 18 months, or a history of peptic ulceration at any time had a barium meal; if this revealed a peptic ulcer the patient was excluded. Patients fulfilling the criteria were taken routinely from those attending the Rheumatism Clinic of the General Infirmary at Leeds.

\section{Design of Trial}

The trial was conducted on an out-patient basis. Observations were made over a preliminary 2-week period to ensure that no major fluctuation in the disease was occurring.

The 24 patients who completed the trial formed six groups. In each of these all three preparations (A, B, C) were given consecutively for 4 weeks each in such a way as to give a Latin Square design for order and preparation (ABC, ACB, BCA, BAC, CAB, CBA). The key to the randomization was held by the pharmacist and physicians in sealed envelopes.

Each patient had twelve numbered bottles containing the week's treatment, which was dispensed by trial number from the pharmacy. Patients were seen weekly for 12 weeks from the start of treatment.

The trial was conducted in three periods of 4 weeks, during each of which the patient received either red phenylbutazone tablets (100 mg. each) and yellow placebo capsules, or yellow indomethacin capsules $(50 \mathrm{mg}$. each) and red placebo tablets, or yellow placebo capsules and red placebo tablets.

Dosage Schedule.-In the first week of each period the patient took with meals $50 \mathrm{mg}$. indomethacin (and one red placebo tablet), or $100 \mathrm{mg}$. phenylbutazone (and one yellow placebo capsule), or one red placebo tablet and one yellow placebo capsule. At the first week's assessment, if there had been no undesirable side-effects, medication was increased by one tablet and one capsule. At the second week's assessment, if there had been no undesirable side-effects, the dosage was again increased 
by one capsule and one tablet. At the third week's assessment, if there had still been no undesirable sideeffects, the dosage was maintained at three capsules and three tablets.

If at the end of any week undesirable side-effects were experienced, the dose was reduced by one tablet and one capsule, unless such side-effects were sufficiently mild to warrant maintaining the drug at the same level, or sufficiently severe to stop it entirely. When mild dyspepsia occurred Aludrox was given and the dose was maintained at the same level for a further week, unless symptoms were sufficiently severe to reduce or stop the drug. If the drug was stopped, the patient was switched on to the next course of treatment immediately. If a patient failed to attend for follow-up she was visited at home the next day.

\section{Assessments}

A full clinical, radiographical, and serological examination of all patients was performed. The functional capacity was classified as normal, adequate, limited, or incapacitated.

$X$ rays of hands and feet were taken and graded as doubtful, mild, moderate, and severe changes of rheumatoid arthritis. The indices used to judge progress at the start of the trial and at the end of each 4-week period were:

(1) Strength of grip $(\mathrm{mm}$. $\mathrm{Hg})$, the mean of two grips being taken for each hand, the right hand being used first.

(2) Patient's own assessment of the degree of pain, recorded as nil (0), mild (1), moderate (2), severe (3), unbearably severe (4).

(3) Patient's own assessment of restriction of movement, recorded as nil (0), mild (1), moderate (2), severe (3), completely crippled (4).

(4) Duration of morning stiffness.

(5) Duration to the onset of fatigue after rising.

(6) Average number of aspirin tablets taken per day (these were given as aspirin enseals $300 \mathrm{mg}$.).

(7) Haemoglobin level.

(8) ESR (mm. in first hour).

(9) White blood count.

The Lansbury systemic index was then calculated from morning stiffness, fatigue time, aspirin intake, grip strength, and ESR (Lansbury, 1958). Sideeffects were noted at each visit, each physician enquiring in exactly the same manner with the question, "Have you any symptoms which you think might be attributable to your new treatment?"

Assessments were made at 2 weeks before the start of the trial and at its commencement by a single physician. If the assessments on these occasions were substantially in agreement, the patient was included in the trial and assessment was made by a second physician independently. Further assessments were made at Weeks 4,8 , and 12 by two physicians independently. Assessments were recorded on a single proforma produced for the purpose. The data were later transferred to a summarizing form, so that the physician at the time of examination did not know his previous assessment or the assessment of his colleague. The summarizing data were the means of the assessments by the two physicians.

\section{Description of Population}

The patients completing the trial ranged in age from 43 to 75 years (mean 52.5). There were four men and twenty women. The duration of the disease ranged from 1 to 25 years (mean 9.4). Seven patients in the past had been treated with corticosteroids, twelve with gold, eight with antimalarial drugs, and five with phenylbutazone. Functionally twelve patients had adequate capacity, nine were limited, and three were incapacitated. Radiologically two patients had doubtful changes, seven mild, five moderate, and ten severe.

At the start of the trial six patients had moderate pain, seventeen had severe pain, and in one it was unbearably severe. Movement was mildly restricted in four, moderately in twelve, and severely in sevenc and one patient was completely crippled. The mean values before treatment are shown in Table $\dot{I}$. The duration of morning stiffness varied between nil and all day. Fatigue came on at periods varying from immediately to 12 hours after rising. Aspirin ingestion varied from $1 \cdot 2$ to $4 \mathrm{~g}$. daily. Grip strength varied from 50 to $235 \mathrm{~mm}$. $\mathrm{Hg}$.

The haemoglobin level varied from 61 to 108 per cent. (mean 85.1 ); it was less than 80 per cent. in seven. ESR varied from 18 to $112 \mathrm{~mm}$. in the $1 \mathrm{st} \mathrm{hr}$.

The Lansbury Systemic Index varied from 54 to 119.

\section{Exclusions}

One patient was excluded because of the development of adrenal insufficiency. She was admitted to hospital $\frac{7}{0}$ with vomiting at the conclusion of the first course of treatment (phenylbutazone) and was found to have $N$ amyloidosis involving the adrenal glands. A second patient was admitted after the first course of treatment $\mathrm{N}$ (indomethacin) with depression. A third was lost to $N$ follow-up whilst she was receiving the first course of $\sigma$ treatment (phenylbutazone).

\section{Results}

The effect of the order of treatment and the $\frac{T}{T}$ effect of the preparations were each assessed for 
significance of difference of the means. The mean of scores are shown in Table $I$. In two patients seven and five items of data respectively were missing over the whole trial period, and the mean of the results obtained during the trial for the patient were substituted. As far as the order of treatments was concerned, the only difference of significance was that the Lansbury Systemic Index was least after the second course of treatment.

The analysis used in Table I demonstrated that pain was significantly improved by the active preparations at the 5 per cent. level. Comparison was made between the mean scores, taking the treatments in pairs with the order effect ignored as the design of the trial allowed. Both the active preparations relieved pain significantly more than the placebo, indomethacin at the 1 per cent. level. The aspirin intake was also significantly less $(P<0.05)$. The duration of morning stiffness was less and the increase in grip strength with phenylbutazone more than with the placebo $(P<0.05)$. There was no significant difference in the Lansbury Systemic Index with any preparation. The ESR rose and the haemoglobin fell more with phenylbutazone than with the placebo. It should be noted that none of the differences between the two active drugs was ever significant. The comparisons are summarized in Table II.

\section{Side-Effects}

Three patients required reduction of dose during the course of treatment. They were all receiving indomethacin. One developed nausea, one a headache, and the third a thumping headache with dizziness, nausea, and vomiting. There was a high incidence of headache with indomethacin (21 per cent.) and of light-headedness and dizziness (12.5
TABLE II

COMPARISON OF MEAN SCORES OF NINE VARIABLES, TAKING THE TREATMENTS IN PAIRS, ORDER EFFECT IGNORED

\begin{tabular}{l|c|c|c}
\hline \multicolumn{1}{c|}{ Variable } & $\begin{array}{c}\text { Placebo } v . \\
\text { Indomethacin }\end{array}$ & $\begin{array}{c}\text { Placebo } v . \\
\text { Phenylbutazone }\end{array}$ & $\begin{array}{c}\text { Indomethacin } v . \\
\text { Phenylbutazone }\end{array}$ \\
\hline Pain & $* *$ & $*$ & - \\
\hline Restriction & - & - & - \\
\hline Morning Stiffness & - & $*$ & - \\
\hline Fatigue & - & - & - \\
\hline Aspirin & $*$ & $*$ & - \\
\hline Grip Strength & - & $*$ & - \\
\hline Hb & - & $*$ & - \\
\hline ESR & - & $*$ & - \\
\hline Lansbury Index & - & - & - \\
\hline
\end{tabular}

${ }^{* * P}<0.01 ;{ }^{*} \mathrm{P}<0.05 ;-$ not statistically significant.

per cent.). Nausea was frequently experienced with this drug (17 per cent.). One patient on phenylbutazone developed dyspepsia which was controlled by antacids.

\section{Design of Trial}

\section{Discussion}

Certain features were incorporated into this trial to overcome difficulties which often arise in a study of this nature. Care was taken that the activity of the arthritis was stable by observations over a preliminary 2-week period. Only if the observations were in substantial agreement was the patient included in the trial. To minimize loss from patients failing to attend, visits were made at home on the following day if the patient did not arrive at the clinic. This probably accounted for the fact that only one patient was lost from the trial by defaulting.

TABLE I

MEAN SCORES OF PARAMETERS ASSESSED IN TRIAL

\begin{tabular}{|c|c|c|c|c|c|c|c|c|c|c|}
\hline \multirow{2}{*}{ Measure } & \multicolumn{2}{|c|}{ Overall } & \multicolumn{4}{|c|}{ Order } & \multicolumn{3}{|c|}{ Drugs } & \multirow[b]{2}{*}{$\mathbf{P}$} \\
\hline & Before & After & 1 st & 2nd & 3rd & $\mathbf{P}$ & Placebo & Indomethacin & Phenylbutazone & \\
\hline Pain & $2 \cdot 75$ & $2 \cdot 04$ & $2 \cdot 08$ & $1 \cdot 87$ & $2 \cdot 17$ & - & $2 \cdot 37$ & $1 \cdot 79$ & $1 \cdot 96$ & * \\
\hline Restriction & $2 \cdot 13$ & $1 \cdot 81$ & $1 \cdot 88$ & $1 \cdot 75$ & $1 \cdot 80$ & - & $1 \cdot 88$ & $1 \cdot 88$ & $1 \cdot 67$ & - \\
\hline Morning Stiffness (hrs) & $3 \cdot 38$ & $3 \cdot 64$ & $3 \cdot 83$ & $2 \cdot 88$ & $4 \cdot 21$ & - & $4 \cdot 25$ & $3 \cdot 65$ & $3 \cdot 02$ & - \\
\hline Fatigue (hrs) & $6 \cdot 38$ & $6 \cdot 96$ & $6 \cdot 83$ & $7 \cdot 25$ & $6 \cdot 80$ & - & $6 \cdot 74$ & $7 \cdot 24$ & $6 \cdot 89$ & - \\
\hline Aspirin Tablets & $8 \cdot 58$ & $7 \cdot 00$ & $7 \cdot 08$ & $6 \cdot 92$ & $7 \cdot 00$ & - & $7 \cdot 75$ & $6 \cdot 62$ & $6 \cdot 62$ & - \\
\hline Grip Strength (mm. Hg) & $107 \cdot 3$ & $111 \cdot 3$ & $109 \cdot 3$ & $113 \cdot 0$ & $111 \cdot 5$ & - & $106 \cdot 8$ & $109 \cdot 9$ & $116 \cdot 2$ & - \\
\hline Hb per cent. & $85 \cdot 1$ & $83 \cdot 7$ & $83 \cdot 3$ & $83 \cdot 5$ & $84 \cdot 3$ & - & $86 \cdot 1$ & $83 \cdot 5$ & $81 \cdot 5$ & - \\
\hline ESR & $54 \cdot 7$ & $49 \cdot 5$ & $55 \cdot 5$ & $46 \cdot 4$ & $46 \cdot 6$ & - & $44 \cdot 6$ & $49 \cdot 3$ & $54 \cdot 6$ & - \\
\hline Lansbury Index & $82 \cdot 46$ & $75 \cdot 08$ & $80 \cdot 29$ & $67 \cdot 78$ & $77 \cdot 18$ & $*$ & $78 \cdot 58$ & $74 \cdot 68$ & $71 \cdot 98$ & - \\
\hline
\end{tabular}


TABLE III

SUMMARY OF REPORTS OF INDOMETHACIN IN THE TREATMENT OF RHEUMATOID ARTHRITIS

\begin{tabular}{|c|c|c|c|c|c|}
\hline Authors & Date & Place & $\begin{array}{l}\text { No. of } \\
\text { Cses }\end{array}$ & Design of Trial & Authors' Conclusion \\
\hline Hart and Boardman & 1963 & London & 52 & Cross-over with placebo & $\begin{array}{l}8 \text { of } 15 \text { cases showed reduction of joint } \\
\text { swelling, } 14 \text { of } 37 \text { without swelling } \\
\text { benefited }\end{array}$ \\
\hline Boland & 1964 & Los Angeles & 51 & Uncontrolled & Inconclusive \\
\hline Rothermich & 1963 & Ohio & $\begin{array}{l}\text { Not } \\
\text { stated }\end{array}$ & Uncontrolled & Great promise \\
\hline Norcross & 1963 & Buffalo, N.Y. & 90 & Uncontrolled & $\begin{array}{l}66 \text { per cent. improved } \\
\text { Steroids reduced in } 11 \text { of } 17 \text { cases } \\
\text { Better than phenylbutazone }\end{array}$ \\
\hline Smyth & 1964 & $\begin{array}{l}\text { Denver, } \\
\text { Colorado }\end{array}$ & 63 & Uncontrolled & $\begin{array}{l}\text { Favourable; steroids reduced in } 20 \text { of } \\
44 \text { cases }\end{array}$ \\
\hline $\begin{array}{l}\text { Catoggio, Centurion, } \\
\text { Alberti, Roldan, and } \\
\text { Canepa }\end{array}$ & 1964 & Buenos Aires & 31 & Double-blind cross-over & $2 / 3$ improved \\
\hline Clark & 1964 & $\begin{array}{l}\text { Memphis, } \\
\text { Tennessee }\end{array}$ & 100 & Uncontrolled & $\begin{array}{l}\text { Functional improvement in } 17 \text { Steroids } \\
\text { reduced in } 34 \text { of } 65 \text { cases }\end{array}$ \\
\hline Kelly & 1964 & Melbourne & 167 & Uncontrolled & Benefit often astonishing in 130 cases \\
\hline Percy and others & 1964 & Newcastle & 24 & $\begin{array}{l}\text { Controlled sequential } \\
\text { cross-over with } \\
\text { phenylbutazone }\end{array}$ & $\begin{array}{l}\text { No difference } \\
\text { Less side-effects than phenylbutazone }\end{array}$ \\
\hline $\begin{array}{l}\text { Wanka, Jones, Wood, } \\
\text { and Dixon }\end{array}$ & 1964 & London & 22 & Double-blind controlled & Alleviated pain and stiffness \\
\hline Hart and Boardman & 1965 & London & 26 & $\begin{array}{l}\text { Double-blind cross-over } \\
\text { with phenylbutazone }\end{array}$ & $\begin{array}{l}\text { Equal symptomatic benefit, but greater } \\
\text { reduction of morning stiffness with } \\
\text { phenylbutazone and of joint swelling } \\
\text { with indomethacin }\end{array}$ \\
\hline Smyth & 1965 & $\begin{array}{l}\text { Denver, } \\
\text { Colorado }\end{array}$ & 55 & $\begin{array}{l}\text { Comparison with placebo } \\
\text { and indomethacin }\end{array}$ & $\begin{array}{l}\text { Suppressed joint inflammation } \\
\text { Improved function gradually }\end{array}$ \\
\hline Thompson and Percy & 1966 & Newcastle & 70 & Uncontrolled & $\begin{array}{l}66 \text { per cent. fairly good or satisfactory } \\
\text { response (patient's estimate) }\end{array}$ \\
\hline Pitkeathley and others & 1966 & Buxton & 41 & $\begin{array}{l}\text { Double-blind cross-over } \\
\text { with aspirin }\end{array}$ & $\begin{array}{l}\text { Not of sufficient value to replace aspirin } \\
\text { except in selected cases }\end{array}$ \\
\hline $\begin{array}{l}\text { Co-operating Clinics } \\
\text { Committee }\end{array}$ & 1967 & USA & 109 & Double-blind cross-over & $\begin{array}{l}\text { No difference between placebo and } \\
\text { indomethacin-treated groups }\end{array}$ \\
\hline Donnelly and others & 1967 & Cardiff & 30 & Double-blind cross-over & $\begin{array}{l}\text { No antiphlogistic effect, but anti-fatigue } \\
\text { effect noted }\end{array}$ \\
\hline Pinals and Frank & 1967 & Boston & 24 & $\begin{array}{l}\text { Double-blind cross-over } \\
\text { with aspirin }\end{array}$ & No advantage over aspirin \\
\hline
\end{tabular}

It has been shown that results obtained in trials in which the previous assessments are known are very different from those in which they are unknown to the observer (Jacobsen, 1965). We obviated this effect by recording assessments on a single sheet and later incorporating them into a master proforma. Similarly, two independent physicians assessed the patient at each attendance and the mean of their readings was taken.

A cross-over design was employed to limit the variability between treatment groups. A 4-week period on each medication was used to ensure that none of the effect was due to retention of the drug from the preceding period. It was felt preferable to design the trial so that the maximum tolerable dose of each preparation was compared, rather than comparison between a standard dose of each drug, since patients vary in their response to drugs and in the side-effects they develop.

It was felt that comparison should be made between indomethacin and phenylbutazone, since it has been claimed that these are similar in effect (Percy, Stephenson, and Thompson, 1964; Hart and Boardman, 1965). It was not easy to make identical tablets of these two drugs and this problem was overcome by giving the patient on each occasion tablets of two different colours, one being active and the other containing placebo, or in one period both containing placebo. An ideal trial might have withheld all other drugs from the patient, but it was not felt ethically desirable to keep patients off salicylates. The salicylate need was therefore included as a parameter of response. 


\section{Effect of Indomethacin}

In acute gout the effect of large doses of indomethacin is such that it is regarded by some as the treatment of choice (Emmerson, 1967). Initial reports raised the hope that in rheumatoid arthritis a similar anti-inflammatory effect might be observed, since it was reported that apart from corticosteroids this was the only drug which reduced the soft tissue swelling in the fingers of rheumatoid patients (Hart and Boardman, 1964). There were further optimistic reports, but the results of other authors were at variance with this (Table III). Pitkeathley, Banerjee, Harris, and Sharp (1967) felt that indomethacin had some value, but not sufficient to replace aspirin which appeared to have a greater analgesic effect. Donnelly, Lloyd, and Campbell (1967) could find no beneficial effect when comparing indomethacin with a placebo and indeed found a tendency for the drug to accelerate the ESR. This effect on the ESR was not substantiated by our study. Donnelly and his colleagues' incremental dose schedule was fixed and remained unaltered despite the occurrence of side-effects or apparent therapeutic response. Our experience was that the drug appeared to be an effective analgesic, judging by the subjective relief of pain and the decrease in aspirin intake. Although phenylbutazone was significantly better than placebo relief of morning stiffness and improvement in grip strength, there was no significant difference in the effect of either drug on any parameter. Indomethacin and phenylbutazone therefore appear to be comparable.

The side-effects of headache and light-headedness which some patients experienced with indomethacin are well known. We did not encounter dyspepsia from this drug, perhaps because of the method of selection. Although other toxic effects have been reported (Healey, 1967), these are rarely serious and indomethacin appears to be a relatively safe drug.

\section{Summary}

A double-blind cross-over trial in 24 patients with rheumatoid arthritis has shown that indomethacin is an effective analgesic. Phenylbutazone also relieved morning stiffness and increased grip strength, but in no way did the two drugs differ significantly in their effect on the parameters measured. Side-effects (headache, light-headedness, and nausea) occurred with indomethacin, but were not serious.

The trial was carefully designed to ensure that the activity of the arthritis was stable, loss of patients from the trial by failure to attend was minimized, and the influence of previous observations was obviated by recording data on separate sheets by two physicians independently. Any order effect was overcome by a Latin Square design; the possible effect of retention of the drug used in the previous period was avoided by a 4-week period of treatment (sufficient to allow full excretion). A variable dosage schedule permitted a maximum dose up to $150 \mathrm{mg}$. indomethacin or $300 \mathrm{mg}$. phenylbutazone daily with weekly observations, and the difference in appearance of the preparations was surmounted by using two placebos each identical with phenylbutazone and indomethacin respectively, and giving both placebos together during one of the treatment periods.

We are grateful to Prof. Max Hamilton for helpful advice and discussion, and to Mrs. B. Antcliffe for secretarial assistance. Dr. R. Hodgkinson kindly made available supplies of indomethacin and placebo capsules.

\section{REFERENCES}

Boland, E. W. (1964). Calif. Med., 100, 145 (Nonspecific anti-inflammatory agents).

Catoggio, P. M., Centurion, A., Alberti, H., Roldan, H., and Canepa, L. (1964). Arthr. and Rheum., 7, 300 (Indomethacin in rheumatoid arthritis: properties, side-effects).

Clark, G. M. (1964). Ibid., 7, 300 (Indomethacin in rheumatoid arthritis).

Co-operating Clinics Committee of the American Rheumatism Association (1967). Clin. Pharmacol. Ther., 8, 11 (A three-month trial of indomethacin in rheumatoid arthritis, with special reference to analysis and inference).

Donnelly, P., Lloyd, K., and Campbell, H. (1967). Brit. med. J., 1, 69 (Indomethacin in rheumatoid arthritis: an evaluation of its anti-inflammatory and side-effects).

Emmerson, B. T. (1967). Ibid., 2, 272 (Regimen of indomethacin therapy in acute gouty arthritis).

Hart, F. Dudley, and Boardman, P. L. (1963). Ibid., 2, 965 (Indomethacin a non-steroid antiinflammatory agent).

- - (1964). Practitioner, 192, 828 (Indomethacin).

- - - (1965). Brit. med. J., 2, 1281 (Indomethacin and phenylbutazone: a comparison).

Healey, L. A. (1967). Bull. rheum. Dis., 18, 483 (An appraisal of indomethacin).

Jacobsen, M. (1965). Brit. J. Psychiat., 111, 545 (The use of rating scales in clinical research).

Kelly, M. (1964). Med. J. Aust., 2, 541 (Indomethacin, remarkable anti-rheumatic drug). 
Lansbury, J. (1958). Arthr. and Rheum., 1, 505 (Report of a three-year study on the systemic and articular indices in rheumatoid arthritis).

Norcross, B. M. (1963). Ibid., 6, 290 (Treatment of connective tissue diseases with a new nonsteroidal compound (indomethacin)).

Percy, J. S., Stephenson, P., and Thompson, M. (1964). Ann. rheum. Dis., 23, 226 (Indomethacin in the treatment of rheumatic diseases).

Pinals, R. S., and Frank, S. (1967). New Engl. J. Med., 276, 512 (Relative efficacy of indomethacin and acetylsalicylic acid in rheumatoid arthritis).

Pitkeathley, D. A., Banerjee, N. R., Harris, R., and Sharp, J. (1966). Ann. rheum. Dis., 25, 334 (Indomethacin in in-patient treatment of rheumatoid arthritis).

Ropes, M. W., Bennett, G. A., Cobb, S., Jacox, R., and Jessar, R. A. (1959). Ibid., 18,49 (1958 Revision of diagnostic criteria for rheumatoid arthritis).

Rothermich, N. O. (1963). Arthr. and Rheum., 6, 295 (Indomethacin : a new pharmacologic approach to the management of rheumatoid disease).

Smyth, C. J. (1965). Ibid., 8, 921 (Indomethacin in rheumatoid arthritis. A comparative objective evaluation with adrenocorticosteroids).

Thompson, M., and Percy, J. S. (1966). Brit. med. J., 1, 80 (Further experience with indomethacin in the treatment of rheumatic disorders).

Wanka, J., and Dixon, A. St. J. (1964). Ann. rheum. Dis., 23, 288 (Treatment of osteo-arthritis of the hip with indomethacin: a controlled clinical trial).

- Jones, L. I., Wood, P. H. N., and Dixon, A. St. J. (1964). Ibid., 23, 218 (Indomethacin in rheumatic diseases: a controlled clinical trial).

L'indométhacine dans le traitment de la polyarthrite rhumatoïde

RÉSUMÉ

Un "double-blind cross-over" essai chez 24 malades atteints de polyarthrite rhumatoïde a démontré que l'indométhacine est un analgésique efficace. La phénylebutazone a aussi soulagé la rigidité ressentie le matin et l'augmentation de l'étreinte des mains, mais les deux médicaments n'avaient différés d'aucune façon marquée dans leurs effets mesurés par les paramètres. Les effets toxiques (maux de tête, vertiges et nausées) avaient lieu avec l'indométhacine, mais n'étaient pas sérieux.

L'essai avait été soigneusement préparé afin d'assurer que l'activité de l'arthrite était stable, que la perte des malades de l'essai par leur non-comparution était minimisée et aussi que l'influence des observations antérieures était évitée en enregistrant les données indépendamment sur des fiches séparées par deux médecins. Un effet possible, du à la répartition des malades, a été surmonté par un Carré Latin; l'effet possible de la rétention du médicament employé pendant une période antérieure était évité par une période de traitement de quatre semaines, suffisante à permettre l'élimination complète. Une posologie variable avait permis une dose maxima de $150 \mathrm{mg}$. d'indométhacine ou de $300 \mathrm{mg}$. de phénylebutazone par jour avec des observations hebdomadaires, et la différence de l'aspect des deux médicaments avait été surmontée par l'usage de deux placebos, chacun identique au phénylebutazone et à l'indométhacine respectivement, et en donnant les deux placebos ensemble pendant une des périodes de traitement.
La indometacina en el tratamiento de la poliartritis Reumatoide

SUMARIo

Un método cruzado dobleciego en 24 pacientes cons poliartritis reumatoide ha revelado que la indometacinees un analgésico eficaz. La fenilbutasona también? alivió la rigidez por las mañanas y aumentó la facultad de asir, pero de ningún modo las drogas difirieron significativamente en su efecto sobre los parámetros medidos. Efectos secundarios (dolor de cabeza, mareo y náusea) ocurrieron con la indometacina, pero no fueron serios.

El experimento fue concebido cuidadosamente para asegurar que la actividad de la poliartritis fuese estable, se redujo al mínimo la pérdida de pacientes por no haber asistido, y se evitó la influencia de previas observaciones mediante la anotación de datos en páginas separadas, por dos médicos, independientemente. Cualquier efecto de órden fue superado empleando una cuadrícula latina; el posible efecto de retención de la droga usada en el período anterior fue evitado mediante un tratamiento de 4 semanas (suficiente para permitir la completa excreción). Una dosificación variable permitió una dosis máxima de hasta $150 \mathrm{mg}$. de indometacina o 300 mg. de fenilbutasona diariamente con observaciones semanales, y la diferencia en el aspecto de los preparados fue solucionada usando dos placebos, cada uno de ellos idéntico a la fenilbutasona y la indometacina, respectivamente, y administrando ambos placebos juntos durante uno de los períodos de tratamiento. 